\title{
Therapeutic hypothermia in cardiac arrest survivors: is rebound hyperthermia a significant issue with intravascular cooling?
}

\author{
T Price ${ }^{*}$, C Poots, H Shields, R McKee \\ From ESICM LIVES 2015 \\ Berlin, Germany. 3-7 October 2015
}

\section{Intr}

Out-of-Hospital Cardiac Arrest (OOHCA) is associated with a poor prognosis. Targeted temperature management (TTM) within Intensive Care (ICU) including therapeutic hypothermia $(\mathrm{TH})$ aims to reduce cerebral reperfusion injury and improve neurological outcomes.

Within Northern Ireland (NI), Craigavon Area Hospital $(\mathrm{CAH})$ is the only ICU to implement TH using an intravascular cooling device (Coolgard $3000^{\circ}$, Alsius $\mathrm{UK}^{\circledR}$ )

The benefit of TH has recently been disputed and many ICUs within NI have since adopted TTM to $36^{\circ} \mathrm{C}$ in survivors of OOHCA [1].

In view of this we aimed to benchmark our use of $\mathrm{TH}$ to $32-34^{\circ} \mathrm{C}$, using intravascular cooling against best practice at the time of data collection.

\section{Objectives}

To assess:

- Demographics of patients receiving TH within CAH ICU

- Implementation, maintenance and temperature control during $\mathrm{TH}$ using intravascular cooling

- Outcomes of patients receiving TH

Against standards used in published reference journals $[2,3]$

\section{Methods}

Retrospective, observational chart-based data collection.

40 patients admitted to CAH ICU, who received TH via intravascular cooling catheter (24/5/2010-30/11/2012),

\footnotetext{
Craigavon Area Hospital, Department of Anaesthesia and Intensive Care,
} Craigavon, Northern Ireland, United Kingdom were identified from the Intensive Care National Audit and Research Centre (ICNARC) database.

35 patients $(87.5 \%)$ had available relevant and complete data.

\section{Results}

\section{Conclusions}

Overall our outcomes for a mixed ICU population with broad inclusion criteria for $\mathrm{TH}$ are comparable with those of published studies [2].

The use of intravascular cooling for $\mathrm{TH}$ was associated with minimal use of muscle relaxants allowing early neurological prognostication in our patient group.

Table 1 Indications for TH.

\begin{tabular}{ll}
\hline OOHCA with shockable rhythm & $46 \%$ \\
\hline OOHCA with non-shockable rhythm & $23 \%$ \\
\hline In-hospital cardiac arrest with shockable rhythm & $11 \%$ \\
\hline In-hospital cardiac arrest with non-shockable rhythm & $8 \%$ \\
\hline Respiratory Arrest & $8 \%$ \\
\hline Attempted suicide by hanging & $4 \%$ \\
\hline
\end{tabular}

Table 2 TH using intravascular cooling.

\begin{tabular}{ll}
\hline Mean time from ROSC to target temperature of $32-34^{\circ} \mathrm{C}$ & 8.3 hours \\
\hline Mean duration of $\mathrm{TH}$ at temperature $<34^{\circ} \mathrm{C}$ & $\begin{array}{l}23.8 \\
\text { hours }\end{array}$ \\
\hline Neuromuscular blockade use & $28.5 \%$ \\
\hline $\begin{array}{l}\text { Rebound hyperthermia }\left(>38^{\circ} \mathrm{C}\right) \text { on cessation of active } \\
\text { cooling }\end{array}$ & $45.1 \%$ \\
\hline Mean duration of rebound hyperthermia & 8.6 hours \\
\hline
\end{tabular}

(c) 2015 Price et al.; This is an Open Access article distributed under the terms of the Creative Commons Attribution License (http:// creativecommons.org/licenses/by/4.0), which permits unrestricted use, distribution, and reproduction in any medium, provided the original work is properly cited. 
Table 3 Outcomes.

\begin{tabular}{ll}
\hline Mean length of ICU stay & $\mathbf{5}$ days \\
\hline ICU Mortality & $45.7 \%$ \\
\hline Destination at Hospital Discharge: Home & $94.1 \%$ \\
\hline Destination at Hospital Discharge: Hospice & $5.9 \%$ \\
\hline 30 day mortality & $60 \%$ \\
\hline
\end{tabular}

However intravascular cooling to $32-34^{\circ} \mathrm{C}$ was associated with prolonged periods of rebound hyperthermia in a significant minority of patients $(45.1 \%$, mean time 8.6 hours).

We believe that $\mathrm{TH}$ to $32-34^{\circ} \mathrm{C}$, using intravascular cooling, increases the risk of developing a rebound hyperthermia that could potentially exacerbate acquired neurological injury.

Our data supports the use of TTM to $36^{\circ} \mathrm{C}$ to mitigate any potential effect of rebound hyperthermia is this patient group.

Published: 1 October 2015

\section{References}

1. Neilson, et al: Targeted Temperature Management at $33^{\circ} \mathrm{C}$ versus $36^{\circ} \mathrm{C}$ after Cardiac Arrest. N Engl J Med 2013, 369:2197-22062.

2. The Hypothermia after cardiac arrest study group: Mild therapeutic hypothermia to improve the neurologic outcome after cardiac arrest. $N$ Engl J Med 2002, 346:549-563.

3. Bernard SA, Gray TW, Buist MD, et al: Treatment of Comatose survivors of cardiac arrest with induced hypothermia. N Engl J Med 2002, 346:557-63.

\section{Submit your manuscript to a SpringerOpen ${ }^{\circ}$ journal and benefit from:}

- Convenient online submission

- Rigorous peer review

- Immediate publication on acceptance

- Open access: articles freely available online

- High visibility within the field

- Retaining the copyright to your article 